\title{
Social Media Analytics Driven Counterterrorism Tool to improve Intelligence Gathering towards Combating Terrorism in Nigeria
}

\author{
Muhammad Lawan Jibril ${ }^{1}$, Ibrahim Alh Mohammed ${ }^{2}$ and Atomsa Yakubu ${ }^{3}$ \\ ${ }^{1,3}$ Mathematics and Computer Science Department, Federal University, Kashere, \\ ${ }^{2}$ Department of Computer Science, Yobe State University, Damaturu, \\ Yobe State, Nigeria \\ Imljtech@gmail.com, ${ }^{2}$ ibrahimsallau@gmail.com, ${ }^{3}$ au.nlaro@gmail.com
}

\begin{abstract}
Terrorism is one of the biggest threats to the peace and stability of Nigeria and has evidently threatened national security and socio-economic developments. The activities of the terrorists have created atmosphere of siege and desolation, which have impediment to trades, investments, peaceful co-existence and stability, as well as sustainable livelihood and development in Nigeria especially in North East and South East Geopolitical Zones. In order to combat this menace of terrorism in Nigeria, there is a need for proactive, reconnaissance, sustainable and invaluable intelligence gathering tools. This paper explain how Social Media Analytics which is one of the big data analytics can be harnessed and tool to generate intelligence gathering of the activities of the terrorists or terrorist' groups such as membership, motivation, and operational modalities, foreclosing sources of inspiration, funding and recruitment through analysis of social media such as youtube, twitter, istagram, facebook among others. The paper recommended some opensource Social Media Analytics available such as Gephi, igraph, NetworkX, and some available commercial Social Media Analytics such as i2 Analyst, Sentinel Visualiser, among others to be used so as to improve intelligence gathering, where all what the Nigeria Security Agents have to do is start entering data so as the analyze the activities of the terrorists activities on social media.
\end{abstract}

Keywords: Social Media Analytics, Big Data, Big Data Analytics, Social Media, Terrorist

\section{Introduction}

Terrorism is a sort of violence that uses one-sided violent approach against civilians. It also engages uneven violent confrontation against a stronger adversary, which could be a state or a group of states [4]. Terrorism is no doubt, it one of the biggest threats to global peace and stability in the contemporary times. Since the beginning of this millennium, the incidences of the terrorism have been on a steady rise worldwide. In Africa, indeed the manifestation of terrorism has been evident in some countries like Cameroon, Somalia, Mali, and Nigeria. In Nigeria, the phenomenon has found expression in the emergence of Boko Haram insurgency in 2009. The Boko Haram appears to be the most visible security threat to the country and launched violent attacks on the Nigerian State, killing thousands of people and destroying public and private properties in different parts of the country [19]. Globally, the group is now labeled as one of the most deadly insurgent/terrorist groups in the world. Like most of the terrorist groups, it seems to defy several counter terrorism measures introduced by the Nigerian government [14].

Social media are computer-mediated tools or online platforms that allow individuals, companies and organizations to create, share, or exchange information, career interests,

Received (July 8, 2017), Review Result (September 26, 2017), Accepted (October 12, 2017) 
ideas, and pictures/videos in virtual communities and networks [19]. The Social Media which have no doubt flooded every facet of human endeavor and are also being taken advantages by terrorists to propagate their extreme ideologies, recruit new members, train their members, communicate and conspire with international linkages, and raise funds among others. Arising from this background, this paper recommends that, the Social Media Analytics as an Indispensable Counterterrorism tool to improve Intelligence Gathering towards Combating Terrorism in Nigeria through analysis of the Social Media platforms such as facebook, twitter. youtube among others so as to uncover the activities of Boko Haram such as membership, motivation, and operational modalities, foreclosing sources of inspiration, funding and recruitment.

\subsection{Social Media and Terrorism}

Social media are web or mobile based interactive platforms through which individuals, communities and organizations to create, share, or exchange information, career interests, ideas, and pictures/videos. Social Media consists of websites such as YouTube (videosharing), Twitter and Tumblr (micro-blogging), Facebook (social networking), StackOverflow (community based question and answering), Delicious (social bookmarking), online wikis, message boards and discussion forums. Social media platforms are highly participatory and collaborative in nature in which users can easily share content and post messages and comments [14].

Because of its cheap affordability, convenience and easy broad-reach of social media platforms, terrorists groups have increasingly use them to propagate their ideologies, spread their messages, recruit members, raise funds and gather intelligence. Today, almost 90 percent of terrorists' activities on the Internet take place via social media platforms [20]. There are many instances where terrorists used social media for their activities, in 2008, Jose Pimentel was arrested for preparing bombs to use in attacking targets in New York City. Before his arrest, Mr. Pimentel had been active on-line. He ran a blog, held two YouTube accounts, and operated a Facebook profile, all dedicated to jihadi propaganda. In another instance, illustrates terrorist recruitment in the homeland via social networking, in December 2009 a group of five men in Washington, DC were arrested in Pakistan for attempting to join militants fighting along the border with Afghanistan. Later to become known as the Virginia Five, they were reportedly contacted by a Taliban recruiter through YouTube after one of the members of the group praised an online video showing attacks on American troops [11].

Notorious terror group, Taliban has been active on Twitter since May 2011, tweeting under the handle @alemarahweb and has more than 7,000 followers. However, the account is currently suspended. In December 2011, it was discovered that the Somaliabased terror cell Al-Shabab was using a Twitter account under the name @HSMPress. Since opening on December 7, 2011, the account has amassed tens of thousands of followers and tweets frequently [5].

In Nigeria, however, terrorist groups particularly Boko Haram and Indigenous People of Biafra (IPOB) have increasingly turned to social media to communicate and motivate their followers and supporters. The groups have exploited social media, most notoriously Youtube and Twitter, to send its propaganda and messaging out to the world and to draw in people vulnerable to radicalization. Arabic-language Twitter account purporting to be the official outlet for a Boko Haram media group called Al-Urwah al-Wuthqa was launched and immediately promoted by key pro-IS media operatives in 2015 and the group have been using exploitation skills to influence propaganda. According to [6], Boko Haram Twitter account has streamed several videos to show the public its success on the ground. According to a report by [6] listed various terrorist uses of Facebook which include the following:-

i. As a way to share operational and tactical information, such as bomb recipes, weapon maintenance and use, tactical shooting, etc. 
ii. As a gateway to extremist sites and other online radical content by linking on Facebook group pages and in discussion forums.

iii. As a media outlet for terrorist propaganda and extremist ideological messaging.

iv. As a wealth of information for remote reconnaissance for targeting purposes.

\section{Limitation of the Study}

Nigeria, like many countries in the world, faces terrorism challenge, which becomes one of the greatest threats to its national security. However, the study only explores how big data analytics called social media analytics can be harnessed by Nigeria Security Agencies to generate intelligence gathering of the activities of notorious terrorist groups such as Boko Haram and Indigenous People of Biafra (IPOB) on various social media towards improving national security. The study only recommended both commercial and open source social media analytics that can be harnessed and used.

\section{Methodology of the Study}

The methodology of the study is qualitative and exploratory in nature using only secondary data obtained through the review of related academic and non-academic publications. Qualitative research methodology involves studies that do not attempt to quantify their results through statistical summary or analysis and it typically involves interviews and observations without formal measurement. On other hand, exploratory research methodology is use to formulate a research problem for more precise or an indepth investigation or for using hypothesis from an operational aspect. The methodology aids the researchers to clarify their understanding to a problem and asses the phenomennon in a new light. Moreover, exploratory research is used when problems are in a preliminary stage, when the topic or issue is new and when data is difficult to collect and it is effective in laying the groundwork that will lead to future studies like this research [15].

The study drew its insights from scholarly exegesis and empirical historical evidences that dangerous terrorist groups in Nigeria are Boko Haram and Indigenous People of Biafra (IPOB). The groups had been using the Social Media to publish a stream of propaganda, including several videos, audios and texts. The paper discussed how big data analytics called Social Media Analytics such as Gephi, igraph could be used to generate intelligence gathering towards combating terrorism in Nigeria.

\subsection{Big Data}

Big data can be defined as data that exceeds the processing capacity of conventional database systems. Therefore, it is too big, moves too fast and doesn't fit the architecture of the structure of database [12]. Data becomes big data when its volume, velocity, or variety exceeds the ability of typically IT systems to ingest, store, analyze, and process it. Many organizations have equipment and expertise to handle large quantities of structured data-but with the increasing volume and faster flows of data, they lack the ability to "mine" it and derive actionable intelligence in a timely way. Not only is the volume of this data growing too fast for traditional analytics, but the speed with which it arrives and the variety of data types necessitates new types of data processing and analytic solutions [17]. There are six characteristic of big data which include the following:-

i. Volume: the quantity of generated and stored data for every second. This determines the value and potential insight- and whether it can actually be considered big data or not

ii. Velocity deals with the pace at which data flows in from sources like business processes, machines, networks and human interaction with things like social media sites, mobile devices, etc. The flow of data is massive and continuous. 
iii. Variety: describes different formats of data that do not lend themselves to storage in structured relational database systems. Thus, it refers to the many sources and types of data both structured and unstructured

iv. Veracity: What is the provenance of the data? Does it come from a reliable source? It is accurate and by extension, complete. Thus, veracity refers to the biases, noise and abnormality in data. Is the data that is being stored, and mined meaningful to the problem being analyzed.

v. Volatility refers to how long is data valid and how long should it be stored. In this world of real time data you need to determine at what point is data no longer relevant to the current analysis

vi. Validity means is the data correct and accurate for the intended use.

However, IBM data scientists break big data into four dimensions: volume, variety, velocity and veracity. Figure 1.1 info graphic explains and gives examples of each.

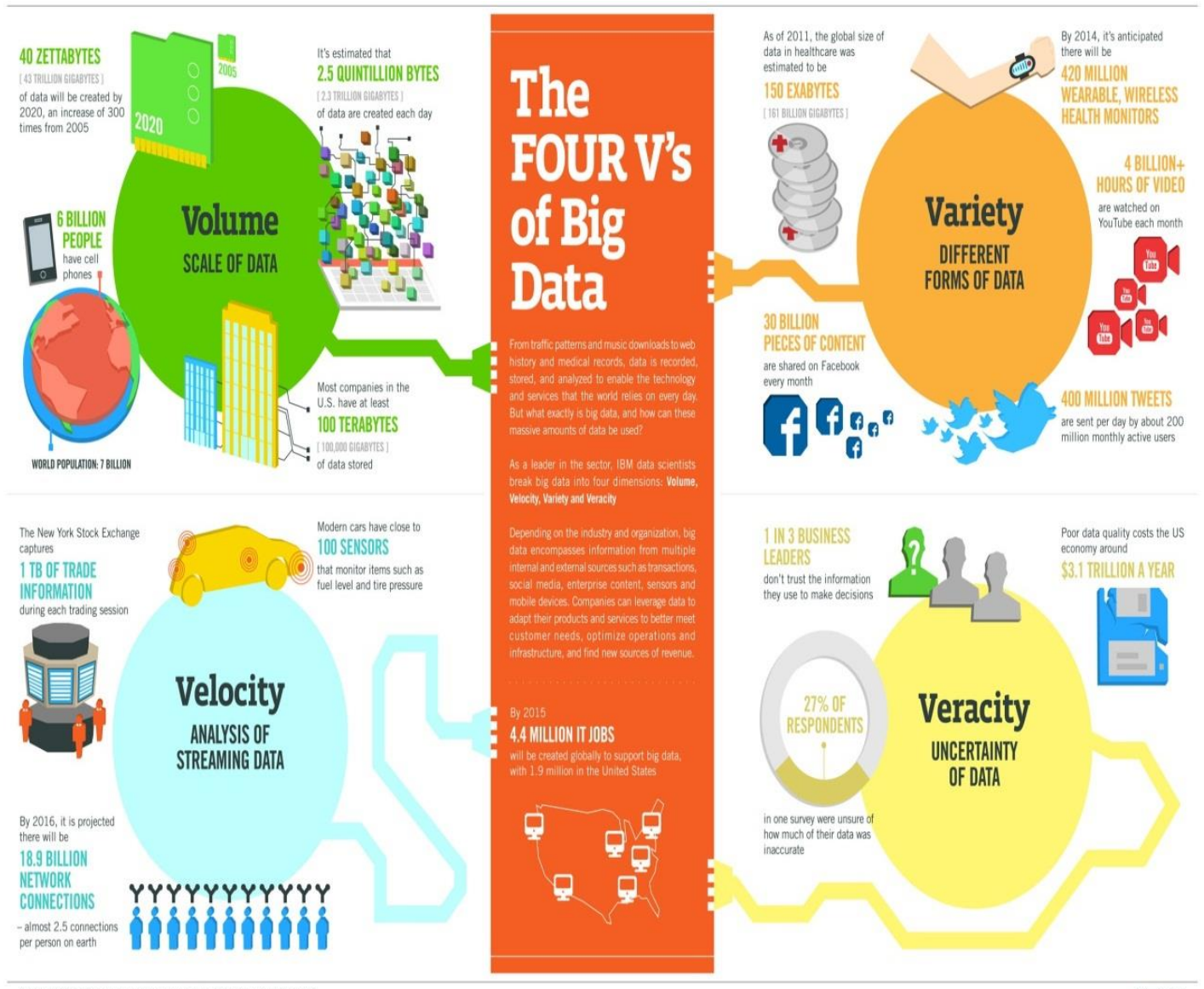

Figure 1.1. IBM Four V's of Big Data

The ways in which Big Data is revolutionizing business are much appreciated because it has transformed the global business landscape. Organization are analyzing hug volumes of diverse, fast changing data gain new insight that help run their business better and get advantage over the competitors. However, the big data may also be leveraged to transform security intelligence gathering landscape. Since the activities of terrorist in Nigeria are in an unstructured form then, the application of Big Data would help to deepen proper understanding of these data for better decision making [16]. 
With Big data, Nigeria may have the ability to achieve superior value from analytics on data at higher volumes, velocities, varieties or veracities. With higher data volumes, Nigeria can take a more holistic view of its security intelligence gathering of the activities terrorists in the past, present and likely future. At higher data velocities, Nigeria can ground its counter terrorism decisions in continuously updated, real-time data. With broader varieties of data, Nigeria can have a more nuanced view of the matter at hand. And as data veracity improves, Nigeria can be confident that it is working with the truest, cleanest, most consistent data.

\subsection{Big Data Analytics}

Big Data Analytics is the use of advanced analytic techniques against very large, diverse data sets that include different types such as structured/unstructured and streaming/batch, and different sizes from terabytes to zettabytes thus big data [13] Big Data Analytics are big data platforms that provide a scalable, robust, and low-cost option to process large and diverse data sets; however, the key is not in organizing and managing large data sets but to generate insights from the data. This is where specialists such as data scientists come into the picture, interpreting and converting the data and relationships into insights. Big data analytics can reveal insights hidden previously by data too costly to process, such as peer influence among customers, revealed by analyzing shoppers' transactions and social and geographical data. Being able to process every item of data in reasonable time removes the troublesome need for sampling and promotes an investigative approach to data, in contrast to the somewhat static nature of running predetermined reports [14].

Nigeria Security Agencies can use big data analytics to uncover patterns in a wide variety of unstructured data generated from social media and associates the patterns with security intelligence gathering outcomes. It can be harnessed to detect unusual, interesting, previously unknown, or new patterns of terrorists' activities particularly Boko haram and Indigenous People of Biafra (IPOB) in data generated from social media.

\subsection{Social Media Analytics}

Social media analytics is a term used to describe the process of gathering and consolidating unstructured raw data from social media channels like Facebook and Twitter and analyzing it to support planning and decision making. It can also be defined as an evaluating big data informatics tool to collect, monitor, analyze, summarize, and visualize social media data so as to extract useful patterns and intelligence [14]. Unstructured data is everything from social media posts and sensor data to email, images and web logs and it is growing at an unprecedented pace and increasing exponentially.

Social Media analytics is been used to process, measure, analyze and interpret the unstructured data generated from interactions and associations among people, topics and ideas discussed on social media and converting them into insights, which help may some businesses in identifying areas of their customer satisfaction or any customer grievance for a product. Likewise, Social Media Analytics can be used to tap and analyze activities of the terrorists on social media platforms, convert them into insight, which may assist Nigeria Security Agencies to identify terrorist' locations and generate early warnings and real-time alerts to improve situational awareness. Therefore, it may to also provide Nigeria Security Agencies with huge amounts of critical, relevant information, including specific events and occurrences, relationships between terrorists (Boko Haram and Indigenous People of Biafra (IPOB)) and their respective affiliated organizations and even recruitment tactics. 


\section{Social Media Analytics: Indispensable Counterterrorism Tool}

Today, there are almost 2.3 billion active social media users in the world; Social media giant Facebook has nearing 1.65 billion users, thus almost a quarter of the world's population and Twitter alone has reported to have 100 million people log in to its site every day. And these numbers are set to increase as social media outlets compete for more users by improving their service. Twitter recently announced new ways for people to share richer content by rolling out a series of changes designed to make the service easier and more intuitive. However, Social media are proving to be valuable tools for terrorists or terrorist groups' internal communication and for reaching larger audiences around the world. In Nigeria, the notorious terror group known as Boko Haram increasingly relies on social media to communicate its message, and builds links with other Islamist organizations. . In January, 2015, the group launched its official Twitter feed - a sign that it is learning from the likes of Al Qaeda and the Islamic State (ISIS) and has repeatedly for over 3 years embarked upon massive propaganda using social media to demoralize the Nigeria Army.

Accessing and analyzing voluminous and unstructured raw data generated from various social media' platforms would be a potential source of intelligence gathering towards improving national security in Nigeria. Therefore, Nigerian Security Agencies may deploy and harness Social Media Analytics to analyze the information that is produced and exists through the social interaction of Nigerians especially among suspected terrorists or terrorist groups on various social media networks so as to improve their intelligence gathering. However, understanding the nature, relationships and content of social media is essential for effective situational awareness, intelligence gathering, counter terrorism and insider threat scenarios. Social Media Analytics can be an indispensable counterterrorism tool that would enable proactive monitoring, analysis, and engagement through extremist social media networks and their associated digital properties such as website. This may help to have a treasure-trove for information on terrorists or terrorist' groups either directly posted or indirectly referred to.

There are many open-source Social Media Analytics available such as Gephi, igraph, NetworkX, SNAP among others which require a fair amount of software development and data analysis and that of commercial ones such as i2 Analyst, Sentinel Visualiser, SilentRunner Sentinel among others, where all what the Nigeria Security Agents have to do is start entering data to analyze the connections between a suspect terrorist and individuals in its relationship network quantitatively and qualitatively, either through numerical or visual representation. The networks can consist of anything from families (immediate and extended); professional links (office colleagues or the suspect's businesscards folder); membership on networking sites such as Facebook, LinkedIn, and Twitter; social circle; mobile phone records; and various others.

Nigeria Security Agencies would be able to analyze social media by harnessing Social Media Analytics for intelligence gathering towards combating terrorism in Nigeria need to, among other things:

i. Detect specific, credible terrorist' threats or monitor adversarial situations.

ii. Geospatially locate terrorists or terrorist groups and analyze their movements, vulnerabilities, limitations, and possible adverse actions.

iii. Predict likely developments in the situation or future actions taken by terrorists or terrorist groups (by conducting trend, pattern, association, and timeline analysis).

iv. Detect instances of deception in intent or action by terrorists or terrorist groups for the explicit purpose of misleading law enforcement.

v. Develop domain assessments for the area of interest (more so for routine scenarios and special events). 


\section{Implications for Nigerian Security Policy and Decision Making}

For effective harnessing of the Social Media Analytics to improve intelligence gathering towards combating terrorism in Nigeria the following challenges need to be addressed:-

i. A big data department in every security agencies, need to be established and be saddled with the responsibility of harnessing the social media analytics to uncover the activities of terrorists or terrorist' groups.

ii. A comprehensive and total synergy relational ship among those departments for collaborative and effective intelligence gathering need to be established maintained and monitored by the Office National Security Adviser.

iii. Highly Qualified Personnel need to be recruited or trained

iv. Uninterrupted power supply and internet service need to be provided at each department concerned

v. All the necessary relevant laws, regulations and policies need to be amended or formulated for effective startup of the usage of the analytics toward improving national security.

\section{Discussion}

Terrorism is of the greatest threat to national security and peaceful co-existence and it spreads fast like wild fire ready to consume and object close to it. Terrorists or Terrorist' Group had since used the various social media to communicate with and motivate their followers and supporters. Therefore, with big data, Nigeria may have the ability to achieve superior value from Social Media Analytics on unstructured data at higher volumes, velocities, varieties or veracities generated from various social media towards improving national security. The paper expatiates how Social Media Analytics can be used as an Indispensable Counterterrorism tool to collect, monitor, analyze, summarize, and visualize unstructured data generated from interactions and associations among terrorists or terrorist' groups so as to improve intelligence gathering towards combating Terrorism in Nigeria. Harnessing the Social Media Analytics for intelligence gathering by Security Agencies in Nigeria towards combating terrorism may help to achieve the following:

i. Capture terrorists' data from various social media to understand their attitudes, opinions and trends and so as to prepare and plan for counter actions.

ii. Predict terrorists' behavior and improve counter actions by anticipating terrorists plans so as to recommend the best counter actions

iii. Create customized campaigns against terrorism that resonate with social media participants.

iv. Identify the primary terrorist recruiters within specific social network channels and target them with unique counter-terrorist action

\section{Conclusion and Future Research}

Social media offer terrorists or terrorist' groups enormous reach of audience that knows no borders or nationalities. With the help of the social media, terrorists or terrorist' groups especially Boko Haram and Indigenous People of Biafra (IPOB) get unlimited access to impressionable young people sharing similar ideas. In order to combat the terrorism in Nigeria, there is need for proactive, reconnaissance, sustainable and invaluable intelligence gathering via analysis of social media for effective counter-terrorism. However, the paper illustrate how Social Media Analytics can be used an Indispensable Counterterrorism tool to improve intelligence gathering and a complementary source of 
intelligence gathering to Security Agencies in Nigeria towards combating terrorism. The study recommends the following as future research:-

i. To review various open source Big Data Social Media Analytics, identify their weaknesses and strengths so as to recommend the best one that would fit our environment.

ii. To review various underlying algorithms for Big Data Social Media Analytics, identify their weaknesses and strengths so as to propose the best algorithm that would fit our environment.

iii.To incorporate one of the best encryption techniques in the proposed algorithm for decrypting, analysis and having insight of encrypted big data generated from social media.

iv. To develop and implement new social media analytics based on such underlying proposed algorithms.

Indeed, Terrorism spreads fast like wild fire ready to consume and object close to it. And the Social media offers terrorists or terrorist' groups enormous reach of audience that knows no borders or nationalities. Uncovering the activities of those Terror Groups on social media is harder than ever. But Big Data Social Media Analytics is the best technology Solution ever.

\section{References}

[1] A. Ahmed, M. Ravichandran, A. Kamarulnizam and D. Sity, "Managing Terrorism and Insurgency through African Traditional Institutions: The Role of Kano Emirate Council -Nigeria", Mediterranean Journal of Social Sciences MCSER Publishing, Rome-Italy. S2, ISSN 2039-2117 (online) ISSN 20399340 (print), vol 6, no 4, (2015), pp. 126 - 136.

[2] A. C. Okoli and P. Iortyer, "Terrorism and Humanitarian Crisis in Nigeria: Insights from Boko Haram Insurgency", Global Journal of HUMAN-SOCIAL SCIENCE F POLITICAL SCEINCE, Type: Double Blind Peer Reviewed International Research Journal Publisher: Global Journals Inc. (USA), Online ISSN: 2249-460x \& Print ISSN: 0975-587X, vol. 14, issue 1, Version 1.0, (2014).

[3] Awareness, "Actionable Social Analystics: From Social Media to Business Insights", (2011).

[4] A. S. Ekaterina, "Terrorism in Asymmetrical Conflict: Ideological and Structural Aspects", New York, NY: Oxford University Press, (2008)

[5] B. Jenkins, "Is Al Qaeda's Internet Strategy Working?", Retrieved july 5, 2016, (2016).

[6] BBC, "Is Islamic State Shaping Boko Haram Media?", BBC News, 4 Mar. 2015, Web, (2015).

[7] C. Dark, "Social Media and Social Menacing", Foreign Policy Association, Retrieved April 5, 2016, (2011).

[8] C. Paul, C. E. Zikopoulos, D. Dirk, D. Thomas and L. George, "Understanding Big Data: Analytics For Enterprise Class Hadoop and Streaming Data", (2012).

[9] C. Prerna, "Telecom White Paper Social Analytics: Tata Consultancy Services (TCS)", http://www.ibmbigdatahub.com/infographic/four-vs-big-data accessed date 19th June, 2016, (2011).

[10] C. Sam, "Big Data Fuels Intelligence Driven Security, Rapid Growth in Security Information Create New capabilities to Defend against the Unknown", (2013).

[11] Department of Homeland Security, "Terrorist Use of Social Networking Facebook Case Study", Public Intelligence, December 5, 2010. http://publicintelligence. net/ufouoles-dhs-terrorist-use-of-socialnetworking-facebook-case-study, Retrieved February 10, 2016, (2015).

[12] D. Edd, "Big Data Now", O’Reilly Media, Inc. Printed in the United States of America, (2012).

[13] IBM, "What is Big Data Analytics?", https://www-01.ibm.com/software/data/infosphere/hadoop/whatis-big-data-analytics.html Accessed date 19th June, 2016, (2016).

[14] D. Zeng, H. Chen, R. Lusch and S-H. Li, "Social media analytics and intelligence", IEEE Intelligent Systems, vol. 25, no. 6, (2010).

[15] I. Ayuba, Terrorism, "A New Challenge to Nigeria'S Stability in the $21^{\text {st }}$ Century", International Affairs and Global Strategy ISSN 2224-574X (Paper) ISSN 2224-8951 (Online), vol.12, (2013).

[16] J. Kietzmann, H. Kristopher, P. M. Ian and S. S. Bruno, "Social media? Get serious! Understanding the functional building blocks of social media", Business Horizons. 54: 241-251. doi:10.1016/j.bushor.2011.01.005, (2011).

[17] M. Saunders, P. Lewis and A. Thornhill, "Research Methods for Business Students", Second Edition, UK, Financial Times, Prentice Hall, (2003). 
[18] M. E Nwanga, E. N. Onwuka, A. M. Aibinu and O. C. Ubadike, "Leveraging Big Data in Enhancing National Security in Nigeria", International Journal of Knowledge, Innovation and Entrepreneurship, vol. 2, no. 2, (2014), pp. 66-80.

[19] Oracle, Big, "Data Analytics, Advanced Analytics in Oracle Database", An Oracle White Paper March 2013, (2013)

[20] R. Buettner, "Getting a Job via Career-oriented Social Networking Sites: The Weakness of Ties", 49th Annual Hawaii International Conference on System Sciences. Kauai, Hawaii: IEEE. doi:10.13140/RG.2.1.3249.2241, (2016).

[21] United States Embassy in Nigeria, "Boko Haram and US Counterterrorism Assistance to Nigeria", www.nigeria.usembassy.gov/ mobile/ factsheet _05142014.html. Retrieved on August 18, 2016 Chomsky, N. (2001). 9-11. New York: Seven Stories Press, (2014).

[22] W. Gabriel, "New Terrorism and New Media", One Woodrow Wilson Plaza 1300 Pennsylvania Avenue, N.W. Washington, DC, USA 20004-3027 202-691-4000, (2014).

[23] W. Oremus, "Twitter of Terror". Slate Magazine", Retrieved from http://www.internetlivestats.com/internet-users-by-country/ Accessed date 24h July, 2016, (2011).

[24] "Nigerian military's declaration of IPOB as terrorist group 'likely prelude to violent crackdown", retrieved from https://www.premiumtimesng.com/regional/ssouth-east/243599-nigerian-militarysdeclaration-ipob-terrorist-group-likely-prelude-violent-crackdown.html accessed date: 18th September, (2017).

[25] L. J. Muhammad, A.G. Ali and I. S. Iliya, "Security Challenges for Building Knowledge-Based Economy in Nigeria", International Journal of Security and its applications, vol. 9, no. 1, (2015), pp. 119-124. 
International Journal of Advanced Science and Technology Vol.107 (2017) 